\title{
Construction of Recombinant Escherichia coli JM109/LBH-10 and Comparison of Its Optimal Condition for Production of Carboxymethyl cellulase with Its Wild Type, Psychrobacter aquimaris LBH--10
}

\author{
Sang-Un Lee ${ }^{1}$, Wa Gao ${ }^{2}$, Chung-Han Chung ${ }^{3}$ and Jin Woo Lee ${ }^{1,2 *}$
}

${ }^{1}$ Department of Medical Bioscience, Graduate School of Donga-A University, Korea

${ }^{2}$ Department of Biotechnology, Dong-A University, Korea

${ }^{3}$ ReSEAT Programs, Korea Institute of Science and Technology Information, Korea

\begin{abstract}
A gene encoding the Carboxymethyl cellulase (CMCase) of a psychrophilic marine bacterium, Psychrobacter aquimaris LBH-10 was cloned in Escherichia coli JMB109. The optimal conditions of rice bran, ammonium chloride, and initial $\mathrm{pH}$ of the medium for cell growth of $E$. coli JM109/LBH-10 were $73.4 \mathrm{~g} / \mathrm{L}, 5.8 \mathrm{~g} / \mathrm{L}$, and 6.5 , respectively, whereas those for production of CMCase were $57.1 \mathrm{~g} / \mathrm{L}, 6.4 \mathrm{~g} / \mathrm{L}$, and 6.7. The optimal temperatures for cell growth and the production of CMCase by E. coli JM109/LBH-10 were found to be and 40 and $35^{\circ} \mathrm{C}$, respectively. The optimal agitation speeds and aeration rates of a $7 \mathrm{~L}$ bioreactor for cell growth and production of CMCase were 480 rpm and $1.0 \mathrm{vvm}$. In this study, the optimal conditions for cell growth and the production of CMCase by E. coli JM109/ $\mathrm{LBH}-10$ were found to be different from those for its wild type, $P$. aquimaris $\mathrm{LBH}-10$. The maximal production of CMCase by $E$. coli JM109/LBH-10 was $576.8 \mathrm{U} / \mathrm{mL}$, which was 1.80 times higher than that by $P$. aquimaris LBH-10.
\end{abstract}

Keywords: Carboxymethyl cellulase; Escherichia coli JM109; Gene cloning; Optimization, Psychrobacter aquimaris; Response surface methodology

\section{Introduction}

Cellulosic materials have great potential for use as cheap and renewable feedstocks for fermentable sugars [1]. The complete enzymatic hydrolysis of cellulosic materials need at least three different types of cellulases; endoglucanase (Carboxymethyl cellulase), exocellobiohydrolase (avicelase), and $\beta$-glucosidase [2]. The enzymatic saccharification of lignocellulosic materials for the production of ethanol was performed by commercial cellulases, in which the major cellulase was Carboxymethyl cellulase [3,4]. Carboxymethyl cellulases (CMCases) have been applied in the textile and detergent industries [5].

Most commercial cellulases are produced by solid state fermentations of fungal species [6]. Enzymes produced by marine microorganisms can provide numerous advantages over traditional enzymes due to the completely different regulatory mechanism for production [7]. A new psychrophilic marine bacterium had been isolated and identified as Psychrobacter aquimaris LBH-10 and characterization of its CMCase was reported [8]. The CMCase produced by this strain showed relatively higher activity at low temperature and acidic stability at $\mathrm{pH}$ 3.5. However, a major restriction in enzymatic saccharification of cellulosic materials is the cost of cellulases and low productivity [9]. One approach to increasing productivity of cellulases would be to isolate hyper-producers or constitutive mutants for cellulases. Another approach would be to clone genes coding for cellulases and then enhance expression of these genes by current molecular genetic techniques $[10,11]$. The gene encoding cold-active esterase of Psychrobacter sp. was cloned and expressed in E. coli [12].

We had reported identification of a psychrophilic marine bacterium, Psychrobacter aquimaris LBH-10 and characterization of the CMCase produced by this strain $[8,13]$. In this study, we described cloning of the CMCase gene of $P$. aquimaris $\mathrm{LBH}-10$ and its expression in E. coli JM109. The optimal conditions for the production of CMCase by a recombinant E. coli JM109 were investigated using response surface methodology (RSM), which were compared with those for its wild strain, $P$. aquimaris LBH-10 $[13,14]$.

\section{Materials and Methods}

\section{Bacterial strain and medium}

Psychrobacter aquimaris LBH-10 had been isolated from seashore of the Kyungsang province in Korea and identified in the previous study [8]. It utilized cellulosic materials such as Carboxymethyl cellulose (CMC), rice bran, and rice hulls and produced carboxymethl cellulase (CMCase). The strain was maintained on agar medium containing 20.0 $\mathrm{g} / \mathrm{L}$ glucose, $2.5 \mathrm{~g} / \mathrm{L}$ yeast extract, $5.0 \mathrm{~g} / \mathrm{L} \mathrm{K}_{2} \mathrm{HPO}_{4}, 1.0 \mathrm{~g} / \mathrm{L} \mathrm{NaCl}, 0.2 \mathrm{~g} / \mathrm{L}$ $\mathrm{MgSO}_{4} \cdot 7 \mathrm{H}_{2} \mathrm{O}, 0.6 \mathrm{~g} / \mathrm{L}\left(\mathrm{NH}_{4}\right) 2 \mathrm{SO}_{4}$, and $15 \mathrm{~g} / \mathrm{L}$ agar.

\section{Cloning and sequence analysis of CMCase}

The full-length CMCase gene of $P$. aquimaris LBH-10 was amplified by polymerase chain reaction (PCR) using two specific primers, 5'-AGGAGGAAAAGATCAGATATGAAACGGTCAATC-3' (forward) and 5'-TCCAGTATTTCATCCACAACGCAAACCTCC-3' (reverse). These primers were designed on the basis of DNA sequences of CMCase genes of Bacillus sp. previously cloned: CMCase genes of B. subtilis AY044252.1 (NCBI-gi: 15375077), B. subtilis Z29076.1 (gi: 509266), and B. subtilis X67044.1 (gi: 39776). The chromosomal DNA

*Corresponding author: Jin Woo Lee, Department of Medical Bioscience, Graduate School of Donga-A University, Busan 604-714, Korea, Tel: +82-51-200 7593; Fax: +82-51-200-7505; E-mail: jwlee@dau.ac.kr

Received February 25, 2014; Accepted March 18, 2014; Published March 21 2014

Citation: Lee SU, Gao W, Chung CH, Lee JW (2014) Construction of Recombinant Escherichia coli JM109/LBH-10 and Comparison of Its Optimal Condition for Production of Carboxymethyl cellulase with Its Wild Type, Psychrobacter aquimaris LBH--10. J Microb Biochem Technol 6: 135-143. doi:10.4172/1948-5948.1000134

Copyright: ( 2014 Lee SU, et al. This is an open-access article distributed under the terms of the Creative Commons Attribution License, which permits unrestricted use, distribution, and reproduction in any medium, provided the original author and source are credited 
Citation: Lee SU, Gao W, Chung CH, Lee JW (2014) Construction of Recombinant Escherichia coli JM109/LBH-10 and Comparison of Its Optimal Condition for Production of Carboxymethyl cellulase with Its Wild Type, Psychrobacter aquimaris LBH--10. J Microb Biochem Technol 6: 135-143. doi:10.4172/1948-5948.1000134

of $P$. aquimaris LBH-10 extracted using a Wizard Genomic DNA Prep. Kit (Promega Co., Madison, USA) was used as a template. PCR amplification was performed as described previously [15]. PCR for amplification was run for 35 cycles in a DNA thermal cycler (Model No. 9700, Perkin-Elmer Co. Wellesley, USA). The following thermal profile was used for the PCR: denaturation at $94^{\circ} \mathrm{C}$ for $1 \mathrm{~min}$, primer annealing at $60^{\circ} \mathrm{C}$ for $1 \mathrm{~min}$, and extension at $72^{\circ} \mathrm{C}$ for $2 \mathrm{~min}$. The final cycle included extension for $10 \mathrm{~min}$ at $72^{\circ} \mathrm{C}$ to ensure full extension of the products. The amplified PCR products were ligated with the T-tail site of pGEM-T Easy Vector System (Promega Co., Madison, USA) and constructed plasmids were transformed into E. coli JM109. The plasmid contained PCR product was isolated from transformed E. coli JM109 and was sequenced in both directions using ALF Red automated DNA sequencer (Pharmacia, Sweden). Analysis of sequence data and sequence similarity searches were performed using the BLAST $(\mathrm{N})$ program of the National Center for Biotechnology Information (NCBI) [16]. The transformed E. coli JM109 harboring the CMCase gene of $P$. aquimaris LBH-10 was named as E. coli JM109/LBH-10.

\section{Production of CMCase by E. coli JM109/LBH-10}

E. coli $\mathrm{JM} 109 / \mathrm{LBH}-10$ was grown at $37^{\circ} \mathrm{C}$ in $\mathrm{LB}$ medium containing $100 \mu \mathrm{g} / \mathrm{mL}$ ampicillin. The main culture for production of CMCase was carried out in the medium containing $20.0 \mathrm{~g} / \mathrm{L} \mathrm{CMC,} 2.5 \mathrm{~g} / \mathrm{L}$ yeast extract, $5.0 \mathrm{~g} / \mathrm{L} \mathrm{K}_{2} \mathrm{HPO}_{4}, 1.0 \mathrm{~g} / \mathrm{L} \mathrm{NaCl}, 0.2 \mathrm{~g} / \mathrm{L} \mathrm{MgSO} \cdot 7 \mathrm{H}_{2} \mathrm{O}$, and 0.6 $\mathrm{g} / \mathrm{L}\left(\mathrm{NH}_{4}\right) 2 \mathrm{SO}_{4}$ for $72 \mathrm{~h}$ under aerobic conditions [8]. After cultivation, cells were removed from the culture broth by centrifugation at 12,000 $\mathrm{x} \mathrm{g}$ for $20 \mathrm{~min}$ and supernatants were dialyzed against deionized water using dialysis tubing with a molecular weight cut-off of 12,000 to $14,000 \mathrm{Da}$.

Batch fermentations for the production of CMCase by E. coli JM109/ LBH-10 were performed in 7 L bioreactors (Ko-Biotech Co., Korea). Working volume of a $7 \mathrm{~L}$ bioreactor was $5 \mathrm{~L}$ and inoculum size of batch fermentation for production of CMCase was $5 \%(\mathrm{v} / \mathrm{v})$. Temperature for batch fermentations was maintained at $35^{\circ} \mathrm{C}$. Agitation was provided by three six-flat-blade impellers in a $7 \mathrm{~L}$ bioreactor.

\section{Experimental design and optimization for production of CMCase}

The rice bran $\left(\mathrm{X}_{1}\right)$, ammonium chloride $\left(\mathrm{X}_{2}\right)$, and initial $\mathrm{pH}$ of the medium $\left(\mathrm{X}_{3}\right)$ were chosen as the independent variables and cell growth $\left(\mathrm{Y}_{1}\right)$ and $\mathrm{CMCase}\left(\mathrm{Y}_{2}\right)$ were used as a dependent output variable. The model constructed as a response function of the variables on cell growth and production of CMCase was a second-order polymial as follows (Equation 1):

$$
\mathrm{Y}=\beta_{0}+\sum \beta_{\mathrm{i}} \mathrm{X}_{\mathrm{i}}+\sum \beta_{\mathrm{ii}} \mathrm{X}_{\mathrm{i} 2}+\sum \beta_{\mathrm{ij}} \mathrm{X}_{\mathrm{i}} \mathrm{X}_{\mathrm{j}}
$$

Where, $\mathrm{y}$ is the measured response (cell growth as measured dry cells weight or production of CMCase), $\beta_{0}, \beta_{i}$, and $\beta_{i j}$ are the regression coefficients, and $X_{i}$ and $X_{i}$ are the factors under study. For three variable systems, the model equation is given below (Equation 2).

$$
Y=\beta_{0}+\beta_{1} X_{1}+\beta_{2} X_{2}+\beta_{3} X_{3}+\beta_{11} X_{12}+\beta_{22} X_{22}+\beta_{33} X_{32}+\beta_{12} X_{1} X_{2}+
$$$$
\beta_{13} X_{1} X_{3}+\beta_{23} X_{2} X_{3}
$$

Regression analysis and estimation of the coefficient were performed using the statistical software, Design-Expert (Version 7.1.6, Stat-Ease Inc., Minneapolis, USA). The contribution of individual parameters and their quadratic and interactive effects on cell growth and production of CMCase were determined. The agitation speed $\left(\mathrm{X}_{1}\right)$ and aeration rate $\left(\mathrm{X}_{2}\right)$ were also chosen as the independent variables and cell growth $\left(\mathrm{Y}_{1}^{\prime}\right)$ and CMCase $\left(\mathrm{Y}_{2}^{\prime}\right)$ were used as a dependent output variable. The interrelationships of the variables were also determined by fitting the second-order polynomial equation. Statistical analysis of the model was performed to evaluate the analysis of variance (ANOVA).

\section{Analytical methods}

CMCase activity was measured by the DNS (3,5-dinitrosalicylic acid) method, through the determination of the amount of reducing sugars liberated from CMC solubilized in $50 \mathrm{mM}$ Tris- $\mathrm{HCl}$ buffer, $\mathrm{pH}$ 8.0 [17]. This mixture was incubated for $20 \mathrm{~min}$ at $50^{\circ} \mathrm{C}$ and the reaction was stopped by the addition of DNS solution. The treated samples were boiled for $10 \mathrm{~min}$, cooled in water for color stabilization, and the optical density was measured at $550 \mathrm{~nm}$. CMCase activity was determined by using a calibration curve for glucose (Sigma-Aldrich Co., UK). One unit of enzyme activity was defined as the amount of enzyme that released 1 $\mu \mathrm{mol}$ of glucose per min. Dry cells weight, as cell growth, was measured by directly weighing the biomass after drying to constant weight at 100 to $105^{\circ} \mathrm{C}$ after collection of cells by centrifugation at $12,000 \mathrm{x}$ g for 10 min. Reducing sugars were determined by using the DNS method [18].

\section{Results and Discussion}

The full-length CMCase gene of $P$. aquimaris LBH-10 was cloned by PCR with primers based on DNA sequences of the CMCase gene of Bacillus species cloned previously [19]. As shown in Figure 1, the open reading frame (ORF) of the cloned gene consists of 1,497 nucleotides encoding a protein of 499 amino acids with a predicted molecular weight of 54,890 Da. Analysis of the putative cleavage site of signal peptide by using the Signal P program was located between Ala-29 and Ala-30 [20]. Comparison of the deduced amino acid sequence of the cloned gene with those of proteins registered in the BLAST database showed the highest identity to the CMCase of Bacillus subtilis (GenBank No. P10475) with 93\% identity, as shown in Table 1.

Most CMCases like xylanase and $\beta$-1,3-1,4-glucanases are modular enzymes, which consist of two or more functional modules, such as catalytic and carbohydrate-binding modules (CBMs), connected to each other via a linker sequence [21]. On the basis of amino acid sequence similarities, as shown in Figure 2, catalytic modules, which are engaged in the hydrolysis of cellulose, are classified into 106 groups in glycoside hydrolase families and CBMs, which bind preferentially to cellulose, are also classified into 45 groups (http://cellwall.genomics. purdue.edu/families/4-3-2-2.html). Computer analysis with the deduced mature amino acid sequence of the CMCase from $P$. aquimaris LBH-10 using CDART program of NCBI revealed a modular enzyme composed of two discrete domains in the following order: a catalytic domain (Gly-31 through Asn-332) of glycoside hydrolase family 5 (GH5) and a family 3 (CBM3) (Glu-350 through His-499). Like the modular organization (GH5/CBM3) in many Bacillus endoglucanases (http://cellwall.genomics.purdue.edu/families/4-3-2-2.html), this enzyme has its catalytic domain in the $\mathrm{N}$-terminal portion and CBM in the C-terminal portion [16].

Effect of carbon and nitrogen sources on cell growth and the production of CMCase by E. coli JM109/LBH-10 were investigated. Carbon sources tested for production of CMCase were $20.0 \mathrm{~g} / \mathrm{L}$ glucose, fructose, maltose, sucrose, rice bran, and rice hulls. Nitrogen sources tested were $2.5 \mathrm{~g} / \mathrm{L}$ malt extract, peptone, tryptone, yeast extract, ammonium sulfate, and ammonium nitrate. The best combination for cell growth of E. coli JM109/LBH-10 was found to be rice bran and 
Citation: Lee SU, Gao W, Chung CH, Lee JW (2014) Construction of Recombinant Escherichia coli JM109/LBH-10 and Comparison of Its Optimal Condition for Production of Carboxymethyl cellulase with Its Wild Type, Psychrobacter aquimaris LBH--10. J Microb Biochem Technol 6: 135-143. doi:10.4172/1948-5948.1000134

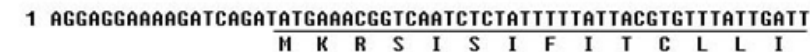
61 ACAGTATTGACAATGGGCGGCTTGCAGGCTTCCCAGGCATCTGCAGCAGGGACAAAAACE \begin{tabular}{llllllllllllllllllll}
\hline & $U$ & $L$ & $T$ & A & G & G & L & Q & A & S & Q & A & $S$ & A & A & G & T & $K$ & $T$
\end{tabular} 121 CCAGCAGCCAAGAATGGGCAGCTTAGCATAAAGGGAACACAGCTCGTAAACCGGGACGGC $\begin{array}{llllllllllllllllllllllll}P & A & A & K & N & G & \mathbf{Q} & L & S & I & K & G & T & \mathbf{Q} & \text { L } & \text { U } & \text { N } & \text { R } & \text { D } & \text { G }\end{array}$ 181 AAAGCGGTACAATTGAAGGGATCAGTTCACATGGATTGCAATGGTATGGCGATITTGTC K $A$ U U C 241 AATAAAGACAGCTTAAAATGGCTGAGAGACGATTGGGGCATAACCGTITTCCGCGCGGCG N K D D S L K W W L R D D W G I T U F R A A 301 ATGTATACGGCAGATGGCGGTTATATTGATAATCCGTCCGTGAAAAATAAAGTAAAAGAB

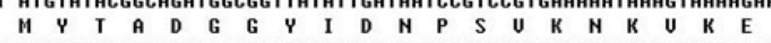
361 GCGGTTGAAGCGGCAAAAGAACTCGGGATATATGTCATCATTGACTGGCATATCTTAAAT $\begin{array}{llllllllllllllllllll}A & U & E & A & A & K & E & L & G & I & Y & U & I & I & D & W & H & I & L & N\end{array}$ 421 GACGGCAACCCAAACCAACATAAAGAGAAGGCAAAAGAATITITTAAGGAAATGTCAAGT D $\quad$ G 481 CIITACGGAACACGCCAARCGTCATITATGAAATTGCAAACGABCCAARCGGTGATGTG L Y N N I P N U I Y E I A N E P N G D U 541 AACTGGAAGCGTGATATTAAACCGTATGCGGAAGAAGTGATITCCGITATCCGCAAAAAT $\begin{array}{llllllllllllllllllll}N & W & K & R & D & I & K & P & Y & A & E & E & U & I & S & U & I & R & K & N\end{array}$ 601 GATCCAGACAACATCATCATTGTCGGAACCGGTACATGGAGCCAAGATGTGAATGATGCA $\begin{array}{llllllllllllllllllll}D & P & D & N & I & I & I & U & G & T & G & T & W & S & Q & D & \text { U } & \text { N } & \text { D } & \text { A }\end{array}$ 661 GCCGATGATCAGCTAAAAGATGCAAACGTCATGTACGCGCITCATITTTATGCCGGCACA A D D D Q L L 721 CACGGCCAATCTITACGGGTAAAGCAAACTATGCACTCAGTAAAGGAGCGCCTATITTC

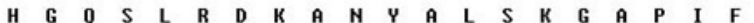
81 GTGACGGAATGGGGACAAGCGACGCGTCTGGAAATGGCGGTSTATTCCITGACCAGTCG U T E U G T S D A S G N G G U F L

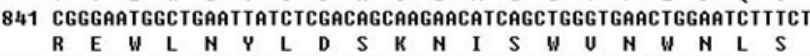
901 GATAAGCAGGAATCATCCTCAGCGITAAAGCCGGGAGCATCTAAAACAGGCGGCTGGCCG $\begin{array}{llllllllllllllllllll}D & K & \mathbf{Q} & E & S & S & S & A & L & K & P & G & A & S & K & \text { T } & \text { G } & \text { G } & \text { V } & \text { P }\end{array}$ 961 CTTACAGATITAACTGCTTCAGGAACATTCGTAAGAGAAAACATTCTCGGCAACAAAGAT

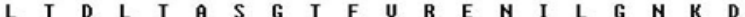
1021 TCAACGAARGAACGCCCTGAAACGCCAGCACAAGATAACCCCGCACAGGAAAACGGCATT $\begin{array}{llllllllllllllllllll}S & T & K & E & R & P & E & T & P & A & Q & D & N & P & A & Q & E & N & G & I\end{array}$ 1081 TCTGTACAATACAAAGCAGGGGATGGGGGTGTGAACAGCAACCAAATCCGCCСGCAGCTT $\begin{array}{llllllllllllllllllll}S & U & Q & Y & K & A & G & D & G & G & \boldsymbol{U} & \mathbf{N} & S & \mathbf{N} & \mathbf{Q} & \mathbf{I} & \mathbf{R} & \mathbf{P} & \mathbf{Q} & \mathbf{L}\end{array}$ 1141 CACATAAAAARTAACGGCAATGCGACGGTTGATTTAAAAGATGTCACTGCCCGITACTGG $\begin{array}{llllllllllllllllllllll}H & I & K & N & \text { N } & G & \text { N } & \text { A } & \text { T } & U & \text { D } & \text { L } & K & \text { C } & \text { U } & \text { T } & \text { A } & \text { B } & \text { Y } & W\end{array}$ 1201 TATAACGCGAAAAACAAGGGCCAคAACTITGACTGTGACTACGCGCAGATTGGATGCGGC

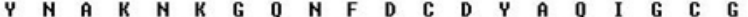
1261 AATCTGACCCACAARTITGTGACGCTGCATAAACCTAAGCAAGGTGCAGATACCTATCTG $\begin{array}{llllllllllllllllllllll}\text { N } & L & \text { T } & \text { H } & \text { K } & \text { F } & \text { U } & \text { T } & \text { L } & \text { H } & \text { K } & \text { P } & \text { K } & \text { Q } & \text { G } & \text { A } & \text { D } & \text { T } & \text { Y } & \text { L }\end{array}$ 1321 GAACTGGGTITAAAACAGGAACGCTGTCACCGGGAGCAAGCACAGGGAATATTCAGCTT $\begin{array}{llllllllllllllllllll}E & L & G & F & K & T & G & T & L & S & P & G & A & S & T & G & N & I & Q & L\end{array}$ 1381 CGTCTTCACAATGATGACTGGAGTAGTIATGCACAAAGCGGCGATATTCCIIITITCAA $\begin{array}{llllllllllllllllllll}\text { R } & L & H & \text { N } & \text { D } & \text { D } & W & S & S & Y & \text { A } & \mathbf{Q} & S & \text { G } & \text { D } & \text { Y } & S & F & F & \mathbf{Q}\end{array}$ 1441 TCAAATACGITTAAAACAACGAAคAAAATTACATTATATCATCAAGGAAAACTGATITGE $\begin{array}{lllllllllllllllllllll}S & N & T & F & K & T & T & K & K & I & T & L & Y & H & 0 & G & K & L & I & V\end{array}$ 1501 GGAACAGAACCCAATTAGTTAAGCTTTAGGCGGACATCAGCAACGATGTCCGCTITTATT G $T$ E $P$ N *

1561 ATCTTAAACAGCAATACATGGAGGTTGCGTTGTGGATGAAATACTGAA

Figure 1: Complete nucleotide and deduced amino acid sequences of the CMCase gene of $P$. aquimaris $\mathrm{LBH}-10$. Asterisk indicates the stop codon. The primers designed for gene cloning were showed under line.

\begin{tabular}{lllll|ll|l|l|l|l|l|lll|lllll} 
LBH-10 & 159 & T & P & N & V & I & Y & E & I & A & N & E & P & N & G & D & V & 174 \\
BACSU & 159 & T & P & N & V & I & Y & E & I & A & N & E & P & N & G & D & V & 174 \\
ERWCT & 158 & S & P & N & V & I & Y & E & I & A & N & E & P & N & G & G & V & 173 \\
BACS4 & 153 & Y & P & N & V & I & Y & E & I & A & N & E & P & N & G & H & N & 168 \\
CLASA & 782 & D & T & I & I & A & F & D & L & K & N & E & P & H & G & K & P & 797 \\
DICD3 & 166 & K & P & N & V & I & Y & E & I & Y & N & E & P & L & Q & V & S & 181 \\
RUMAL & 125 & K & T & N & V & I & Y & E & I & C & N & E & P & N & C & S & G & 140 \\
BACS6 & 363 & N & H & Y & I & I & W & E & L & A & N & E & P & S & P & N & N & 378 \\
PSEFL & 493 & S & N & L & I & G & I & D & V & F & N & E & P & Y & D & Y & T & 508 \\
CLOLO & 175 & D & D & H & L & I & F & E & T & L & N & E & P & R & L & E & G & 190 \\
CLOSF & 130 & R & E & H & I & A & F & E & L & L & N & E & V & V & E & P & D & 145 \\
PAEBA & 177 & N & E & R & L & I & F & E & S & M & N & E & V & F & D & G & N & 191 \\
PAELA & 167 & P & S & K & L & M & F & E & S & V & N & E & P & R & F & T & D & 182
\end{tabular}

Figure 2: Comparison of amino acid sequence alignment of the CMCase produced by $P$. aquimaris $\mathrm{LBH}-10$ and other glycosyl hydrolasefamily 5 using Clustal W, a multiple alignment program. Amino acid sequence alignments of the CMCase produced by $E$. coli JM109/LBH-10 (LBH-10) from BACSU (P10475), ERWCT (Q59394), BACS4 (P06566), CALSA (P10474), DICD3 (P071030, RUMAL (Q079400, BACS6 (P19424), PDEFL (P270330), CLOLO (P549370, CLOSF (P23340), PAELA (P23550), and PAEBA (O08342). yeast extract, whereas that for production of CMCase was fructose and yeast extract, as shown in Figure 3. The production of CMCase from $20.0 \mathrm{~g} / \mathrm{L}$ fructose and $5.0 \mathrm{~g}$ g/L yeast extract was $381.5 \mathrm{U} / \mathrm{mL}$. The best combination of carbon and nitrogen sources for cell growth of $E$. coli JM109/LBH-10 was different from that for production of CMCase.

The best combination of carbon and nitrogen source for cell growth of $P$. aquimaris LBH-10 was sucrose and malt extract, whereas that for production of CMCase was rice bran and peptone [13]. The best carbon and nitrogen sources for cell growth and well as those for production of CMCase by E. coli JM109/LBH-10 were found to be different from those for its wild type, $P$. aquimaris $\mathrm{LBH}-10$. The best carbon and nitrogen sources for cell growth of $B$. amyloliquefaciens DL-3 were sucrose and malt extract, whereas those for production of CMCase were rice hulls and peptone [22]. However, the best carbon and nitrogen sources for cell growth of its recombinant E. coli JM109/ DL-3 were fructose and ammonium chloride, whereas those for

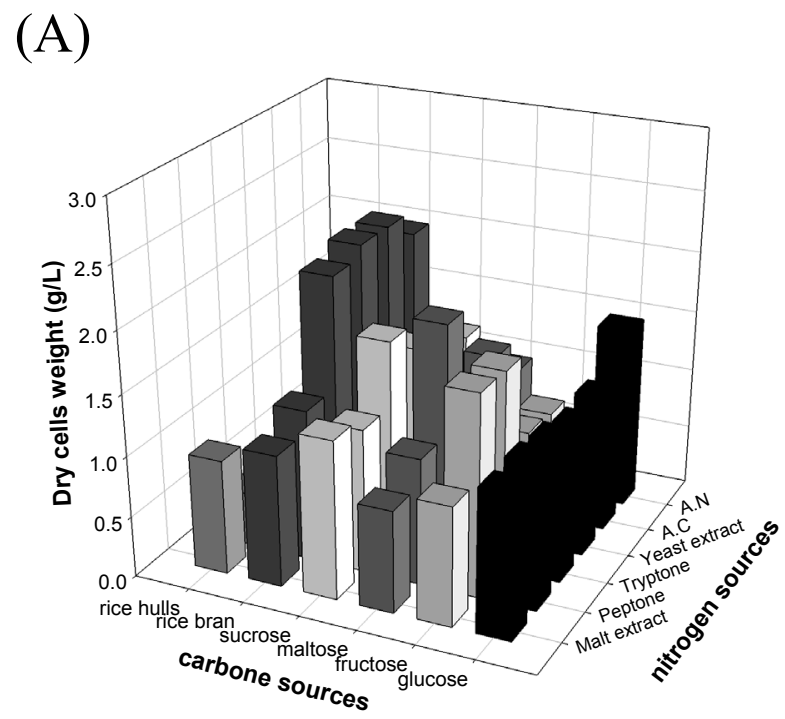

(B)

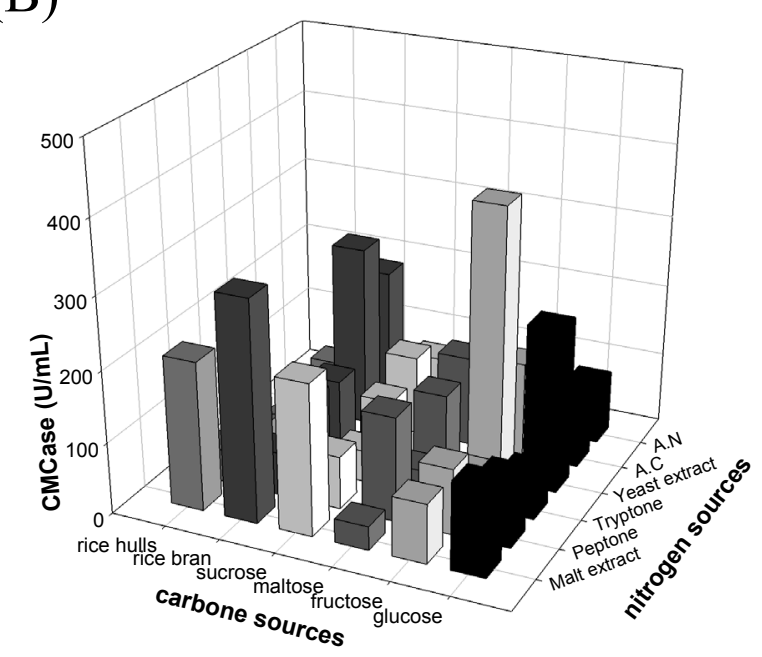

Figure 3: Effect of carbon and nitrogen sources on cell growth $(A)$ and production of CMCase (B) by E. coli JM109/LBH-10. 
Citation: Lee SU, Gao W, Chung CH, Lee JW (2014) Construction of Recombinant Escherichia coli JM109/LBH-10 and Comparison of Its Optimal Condition for Production of Carboxymethyl cellulase with Its Wild Type, Psychrobacter aquimaris LBH--10. J Microb Biochem Technol 6: 135-143. doi:10.4172/1948-5948.1000134

production of CMCase were rice bran and tryptone [23]. The best carbon and nitrogen source for cell growth and production of CMCase by $B$. subtilis subsp. subtilis A-53 were also different from those for its recombinant E. coli JM109/A-53 [11,17]. Based on cost and availability of nitrogen sources, a combination of rice bran and ammonium chloride was chosen for next examination $[24,25]$. The production of CMCase by E. coli JM109/LBH-10 was $254.3 \mathrm{U} / \mathrm{mL}$ from $20.0 \mathrm{~g} / \mathrm{L}$ rice bran and $5.0 \mathrm{~g} / \mathrm{L}$ ammonium chloride.

The optimal conditions of rice bran, ammonium chloride, and initial $\mathrm{pH}$ of the medium for cell growth and the production of CMCase by E. coli JM109/LBH-10 were investigated using 'onefactor-at-a time' experiments. Composition of basic medium was 50.0 $\mathrm{g} / \mathrm{L}$ rice bran, $7.5 \mathrm{~g} / \mathrm{L}$ ammonium chloride, and initial $\mathrm{pH}$ of 7.0 . The optimal conditions of rice bran, ammonium chloride, and initial $\mathrm{pH}$ for the cell growth of $E$. coli JM109/LBH-10 were $100.0 \mathrm{~g} / \mathrm{L}, 7.5 \mathrm{~g} / \mathrm{L}$, and 7.0, respectively, whereas those for production of CMCase were $50.0 \mathrm{~g} / \mathrm{L}, 7.5 \mathrm{~g} / \mathrm{L}$, and 7.0, as shown in Figure 4. The simultaneous effect of rice bran, ammonium chloride, and initial $\mathrm{pH}$ of the medium on cell growth and the production of CMCase by E. coli JM109/LBH-10 were also investigated using response surface methodology (RSM). The coded values of minimum and maximum ranges of rice bran $\left(\mathrm{X}_{1}\right)$, ammonium chloride $\left(\mathrm{X}_{2}\right)$, and initial $\mathrm{pH}$ of the medium $\left(\mathrm{X}_{3}\right)$ were 25.0 and $75.0 \mathrm{~g} \mathrm{~g} / \mathrm{L}, 5.0$ and $10.0 \mathrm{~g} / \mathrm{L}$, and 6.0 and 8.0, respectively. Cell growth, measured as dry cells weight (DCW), and production of CMCase from 20 different conditions ranged from 4.72 to $6.81 \mathrm{~g} / \mathrm{L}$ and from 310.7 to $396.7 \mathrm{U} / \mathrm{mL}$, as shown in Table 2. Multiple regression analysis of the experimental data gave the following second-order polynomial equation to represent cell growth of E. coli JM109/LBH10 (Equation 3). The optimal conditions of rice bran, ammonium chloride, and initial $\mathrm{pH}$ of the medium for cell growth extracted by Design Expert Software were $73.4 \mathrm{~g} / \mathrm{L}, 5.80 \mathrm{~g} / \mathrm{L}$, and 6.54, respectively. The maximum cell growth of $6.21 \mathrm{~g} / \mathrm{L}$ was predicted by this model.

$$
\mathrm{Y}_{1}=5.69+0.55 \mathrm{X}_{1}+0.04 \mathrm{X}_{2}+0.01 \mathrm{X}_{3}+0.01 \mathrm{X}_{1} \mathrm{X}_{2}-0.03 \mathrm{X}_{1} \mathrm{X}_{3}+
$$
$0.04 \mathrm{X}_{2} \mathrm{X}_{3}+0.05 \mathrm{X}_{12}-0.02 \mathrm{X}_{22}-0.13 \mathrm{X}_{32}$

Adequacy of the model was tested by the fisher's statistical test for the analysis of variance (ANOVA), as shown in Table 3. The model F-value of 26.29 from the analysis of variance (ANOVA) of cell growth implied that this model was significant. There was only a $0.01 \%$ chance that a "Model F-value" could occur to die to noise. The ANOVA indicated that this model and the model term of $\mathrm{X}_{1}$ ("probe $>$ F" less 0.0001 ) were highly significant and that of $\mathrm{X}_{32}$ ("probe $>$ F" less 0.0500 )

\begin{tabular}{|c|c|c|c|c|}
\hline Homologous protein & Organism & Identity (\%) & Positive (\%) & GenBank \\
\hline BACSU & Bacillus subtilis & 93 & 96 & P10475 \\
\hline ERWCT & Erwinia carotovora subsp. atroseptica & 56 & 73 & Q59394 \\
\hline BACS4 & Bacillus sp. Strain N-4 & 56 & 71 & P06566 \\
\hline CALSA & Caldocellum saccharolyticum & 44 & 60 & P10474 \\
\hline DICD3 & E. chrysanthemi strain 3937 & 41 & 58 & P07103 \\
\hline RUMAL & Ruminococcus albus & 38 & 60 & Q07940 \\
\hline BACS6 & Bacillus sp. Strain KSM-635 & 35 & 52 & P19424 \\
\hline PSEFL & Pseudomonas fluorescens & 34 & 47 & P27033 \\
\hline CLOLO & Clostridium longisporum & 24 & 41 & P54937 \\
\hline CLOSF & Clostridium sp. strain F1 & 22 & 48 & P23340 \\
\hline PAELA & Paenbacillus lautus & 21 & 42 & P23550 \\
\hline PAEBA & P. barcinonensis & 20 & 47 & 008342 \\
\hline
\end{tabular}

*The amino acid sequences were compared using the NCBI's BLAST search

Table 1: Comparisons of CMCase produced by E. coli JM109/LBH-10 with the glycosyl hydrolase family $5^{*}$.

\begin{tabular}{|c|c|c|c|c|c|}
\hline Run & $X_{1}(g / L)$ & $X_{2}(g / L)$ & $\mathbf{X}_{3}$ & $Y_{1}(g / L)$ & $Y_{2}(\mathrm{U} / \mathrm{mL})$ \\
\hline 1 & 75 & 5.0 & 8.0 & $5.99 \pm 0.23$ & $367.1 \pm 25.2$ \\
\hline 2 & 50 & 7.5 & 7.0 & $5.71 \pm 0.31$ & $389.7 \pm 33.6$ \\
\hline 3 & 50 & 7.5 & 7.0 & $5.82 \pm 0.34$ & $392.7 \pm 28.4$ \\
\hline 4 & 50 & 7.5 & 7.0 & $5.86 \pm 0.44$ & $396.7 \pm 35.8$ \\
\hline 5 & 25 & 10.0 & 8.0 & $5.21 \pm 0.36$ & $346.8 \pm 29.7$ \\
\hline 6 & 75 & 10.0 & 8.0 & $6.19 \pm 0.42$ & $369.3 \pm 30.2$ \\
\hline 7 & 8 & 7.5 & 7.0 & $4.72 \pm 0.23$ & $310.7 \pm 28.7$ \\
\hline 8 & 50 & 3.3 & 7.0 & $5.49 \pm 0.42$ & $378.6 \pm 33.9$ \\
\hline 9 & 25 & 10.0 & 6.0 & $5.15 \pm 0.36$ & $347.5 \pm 30.8$ \\
\hline 10 & 25 & 5.0 & 6.0 & $5.06 \pm 0.42$ & $345.4 \pm 28.7$ \\
\hline 11 & 50 & 7.5 & 8.7 & $5.29 \pm 0.28$ & $386.2 \pm 35.2$ \\
\hline 12 & 75 & 10.0 & 6.0 & $6.12 \pm 0.42$ & $370.0 \pm 25.6$ \\
\hline 13 & 50 & 7.5 & 7.0 & $5.66 \pm 0.33$ & $387.7 \pm 29.5$ \\
\hline 14 & 50 & 7.5 & 5.3 & $5.22 \pm 0.24$ & $386.3 \pm 36.3$ \\
\hline 15 & 50 & 7.5 & 7.0 & $5.60 \pm 0.34$ & $381.5 \pm 42.5$ \\
\hline 16 & 92 & 7.5 & 7.0 & $6.81 \pm 0.42$ & $363.5 \pm 33.8$ \\
\hline 17 & 25 & 5.0 & 8.0 & $5.12 \pm 0.31$ & $344.6 \pm 29.7$ \\
\hline 18 & 50 & 7.5 & 7.0 & $5.52 \pm 0.43$ & $382.5 \pm 28.2$ \\
\hline 19 & 75 & 5.0 & 6.0 & $6.21 \pm 0.44$ & $367.9 \pm 32.7$ \\
\hline 20 & 50 & 11.7 & 7.0 & $5.65 \pm 0.28$ & $383.5 \pm 33.6$ \\
\hline
\end{tabular}

Table 2: Central composite design (CCD) and determined response values. 
Citation: Lee SU, Gao W, Chung CH, Lee JW (2014) Construction of Recombinant Escherichia coli JM109/LBH-10 and Comparison of Its Optimal Condition for Production of Carboxymethyl cellulase with Its Wild Type, Psychrobacter aquimaris LBH--10. J Microb Biochem Technol 6: 135-143. doi:10.4172/1948-5948.1000134

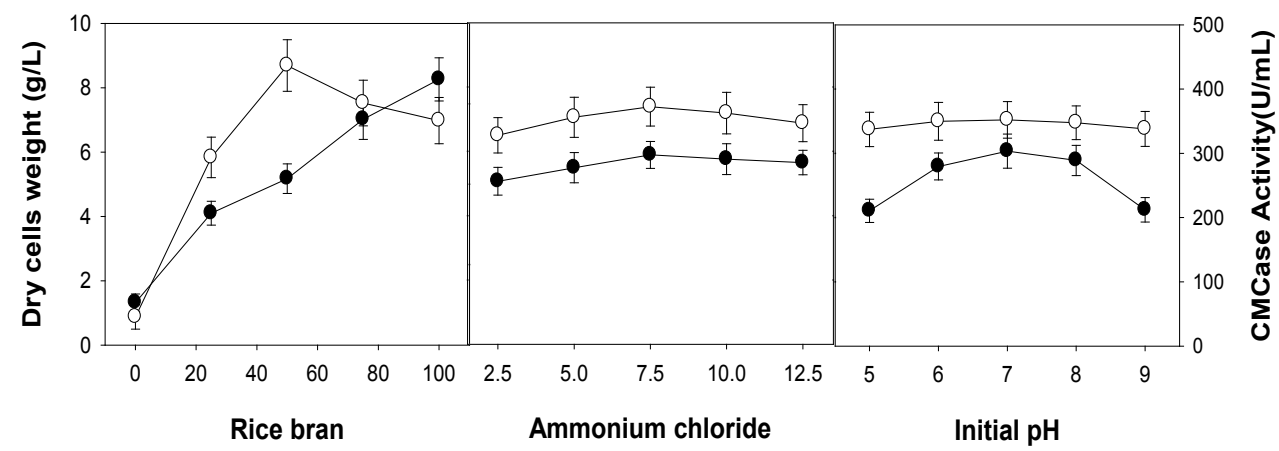

Figure 4: Effect of rice bran, ammonium chloride, and initial pH of the medium on cell growth and production of CMCase by E. coli JM109/LBH-10 ( $\bullet$, cell growth and $\circ, \mathrm{CMCase})$.

\begin{tabular}{|c|c|c|c|c|c|c|}
\hline & Source of variation & Degree of freedom & Sum of squares & Mean squares & $F$-value & Probe $>F$ \\
\hline \multirow{9}{*}{ Cell growth } & Model & 9 & 4.45 & 0.49 & 26.29 & $<0.0001$ \\
\hline & $X_{1}$ & 1 & 4.10 & 4.10 & 217.87 & $<0.0001$ \\
\hline & $\mathrm{X}_{2}$ & 1 & 0.02 & 0.02 & 1.22 & 0.2961 \\
\hline & $\mathrm{X}_{3}$ & 1 & 0.00 & 0.00 & 0.03 & 0.8661 \\
\hline & $\mathrm{X}_{1}^{2}$ & 1 & 0.03 & 0.03 & 1.78 & 0.2117 \\
\hline & $x_{2}^{2}$ & 1 & 0.00 & 0.00 & 0.33 & 0.5792 \\
\hline & $\mathrm{X}_{3}{ }^{2}$ & 1 & 0.25 & 0.25 & 13.35 & 0.0044 \\
\hline & Error & 5 & 0.08 & 0.02 & - & - \\
\hline & Total & 19 & 4.64 & - & - & - \\
\hline \multirow{9}{*}{ CMCase } & Model & 9 & 8307.01 & 923.00 & 17.63 & $<0.0001$ \\
\hline & $\mathrm{X}_{1}$ & 1 & 2338.26 & 2338.26 & 44.66 & $<0.0001$ \\
\hline & $\mathrm{X}_{2}$ & 1 & 20.52 & 20.52 & 0.39 & 0.5453 \\
\hline & $\mathrm{X}_{3}$ & 1 & 0.78 & 0.78 & 0.02 & 0.9051 \\
\hline & $\mathrm{X}_{1}^{2}$ & 1 & 5844.92 & 5844.92 & 111.64 & $<0.0001$ \\
\hline & $x_{2}^{2}$ & 1 & 304.99 & 304.99 & 5.83 & 0.0365 \\
\hline & $X_{3}^{2}$ & 1 & 109.93 & 109.93 & 2.10 & 0.1780 \\
\hline & Error & 5 & 164.23 & 32.85 & - & - \\
\hline & Total & 19 & 8830.57 & - & - & - \\
\hline
\end{tabular}

Table 3: Parameter estimates and analysis of variance (ANOVA) of the design for cell growth and production of CMCase by E. coli JM109/LBH-10.

was significant for the cell growth of E. coli JM109/LBH-10. The regression equation obtained from ANOVA indicated that the multiple correlation coefficient of $\mathrm{R}_{2}$ was 0.9594 , which could explain $95.94 \%$ variation in the response. The value of the adjusted determination coefficient (Adj. $R_{2}=0.9229$ ) was very high to advocate for a high significance of this model $[26,27]$. The predicted determination of coefficient of 0.8001 was in reasonable agreement with the Adj. $R_{2}$ of 0.9229 . From the statistical results obtained, it was shown that the above models were adequate to predict the cell growth of E. coli JM109/ LBH-10 within the range of variables studied.

Multiple regression analysis of the experimental data also gave the following second-order polynomial equation to represent the production of CMCase by E. coli JM109/LBH-10 (Equation 4). The optimal conditions of rice bran, ammonium chloride, and initial $\mathrm{pH}$ of the medium for production of CMCase were $57.1 \mathrm{~g} / \mathrm{L}, 6.40 \mathrm{~g} / \mathrm{L}$, and 6.70, respectively. The maximum production of CMCase of $388.9 \mathrm{U} /$ $\mathrm{mL}$ was predicted by this model.

$\mathrm{Y}_{2}=388.66+13.08 \mathrm{X}_{1}+1.23 \mathrm{X}_{2}-0.24 \mathrm{X}_{3}+0.01 \mathrm{X}_{1} \mathrm{X}_{2}+0.01 \mathrm{X}_{1} \mathrm{X}_{3}+$ $0.04 \mathrm{X}_{2} \mathrm{X}_{3}-20.14 \mathrm{X}_{12}-4.60 \mathrm{X}_{22}-2.76 \mathrm{X}_{32}$

The model F-value of 17.63 from the ANOVA of production of CMCase implied that this model was also significant. The ANOVA indicated that this model and model terms of $\mathrm{X}_{12}$ were highly significant. The regression equation obtained from ANOVA indicated that the multiple correlation coefficient of $R_{2}$ was 0.9407 . The value of the adjusted determination coefficient (Adj. $R_{2}=0.8874$ ) was high to advocate for a high significance of this model. The predicted determination of coefficient of 0.6658 was also in reasonable agreement with the Adj. $\mathrm{R}_{2}$ of 0.8874 . From the statistical results obtained, it was shown that the above models were adequate to predict the production of CMCase by E. coli JM109/LBH-10 within the range of variables studied.

The optimal conditions for the production of CMCase by $P$. aquimaris $\mathrm{LBH}-10$ were $50.0 \mathrm{~g} / \mathrm{L}$ rice bran, $3.0 \mathrm{~g} /$ peptone, and initial $\mathrm{pH}$ of 8.0 [13]. The percent participation of rice bran, peptone, and initial $\mathrm{pH}$ for production of CMCase were 52.0, 47.8, and $0.2 \%$, respectively. The optimal conditions for the production of CMCase by E. coli JM109/LBH-10 were $57.1 \mathrm{~g} / \mathrm{L}$ rice bran, $6.40 \mathrm{~g} / \mathrm{L}$ ammonium chloride, and initial $\mathrm{pH}$ of 6.70 . The rice bran was found to be highly significant for the production of CMCase by E. coli JM109/LBH-10. However, ammonium chloride and initial $\mathrm{pH}$ were not significant for production of CMCase. The significant factor for the cell growth of E. coli JM109/DL-3 was rice bran, whereas those for production of CMCase were rice bran and initial $\mathrm{pH}$ of the medium [10]. The 
Citation: Lee SU, Gao W, Chung CH, Lee JW (2014) Construction of Recombinant Escherichia coli JM109/LBH-10 and Comparison of Its Optimal Condition for Production of Carboxymethyl cellulase with Its Wild Type, Psychrobacter aquimaris LBH--10. J Microb Biochem Technol 6 : 135-143. doi:10.4172/1948-5948.1000134

optimal conditions and significance of each factor for the production of CMCase by E. coli JM109/LBH-10 were different from those for $P$. aquimaris LBH-10 as previously reported [11,17].

The effect of temperature on cell growth and the production of CMCase by E. coli JM109/LBH-10 were investigated. The temperature for cell growth and production of CMC ranged from 25 to $45^{\circ} \mathrm{C}$. The carbon and nitrogen source and initial $\mathrm{pH}$ of the medium were 57.1 $\mathrm{g} / \mathrm{L}$ rice bran, $6.4 \mathrm{~g} / \mathrm{L}$ ammonium chloride, and 6.7, respectively. The optimal temperatures for cell growth and the production of CMCase by $E$. coli JM109/LBH-10 were found to be 40 and $35^{\circ} \mathrm{C}$, respectively, as shown in Figure 5. Cell growth and the production of CMCase by $E$. coli JM109/LBH under optimized conditions were $6.12 \mathrm{~g} / \mathrm{L}$ and 523.2 $\mathrm{U} / \mathrm{mL}$. Significance of each value was analyzed by MYSTAT software (Systat Software, Inc., Chicago, USA).

The optimal temperatures for cell growth and the production of CMCase by $P$. aquimaris LBH- 10 were 25 and $30^{\circ} \mathrm{C}$, respectively [13]. Those for production of CMCases by bacterial and fungal stains ranged from 25 to $37^{\circ} \mathrm{C}$, except for thermophilic microorganisms such as Thermoascus aurantiacu, which optimal temperature for production of CMCase is $50^{\circ} \mathrm{C}$ [23]. The optimal temperature for the cell growth of a psychrophilic marine bacterium, $P$. aquimaris LBH-10 was lower than that for production of CMCase. However, the optimal temperature for the cell growth of its recombinant E. coli JM109/LBH-10 was higher than that for production of CMCase. The optimal temperatures for cell growth and the production of CMCase by $B$. subtilis subsp. subtilis A-53 were 35 and $30^{\circ} \mathrm{C}$, respectively, whereas those for its recombinant E. coli JM109/A-53 were 40 and $35^{\circ} \mathrm{C}[11,17]$. The optimal temperatures for cell growth and the production of CMCase by E. coli JM109/LBH10 were also different from those for $P$. aquimaris LBH-10 such as other recombinants, E. coli JM109/A-53 and E. coli JM109/DL-3.

The effect of agitation speed on cell growth and the production of CMCase by E. coli JM109/LBH-10 in a 7 L bioreactor were investigated using one-factor-at-a-time. Carbon and nitrogen sources for production of CMCase were $57.0 \mathrm{~g} / \mathrm{L}$ rice bran and $6.4 \mathrm{~g} / \mathrm{L}$ ammonium chloride. The initial $\mathrm{pH}$ of the medium and temperature were 6.7 and $35^{\circ} \mathrm{C}$. Agitation speed ranged from 200 to $500 \mathrm{rpm}$ and aeration rate was $1.0 \mathrm{vvm}$. Higher agitation speeds and aeration rates, which resulted in an increase of dissolved oxygen in the medium, enhanced cell growth as well as production of CMCase, as shown in Figure 6. The optimal agitation speeds for cell growth and production of CMCase were $500 \mathrm{rpm}$. The effect of aeration rate on cell growth and production of CMCase also was investigated. Aeration rate ranged from 0.5 to $2.0 \mathrm{vvm}$ and the agitation speed was fixed to $500 \mathrm{rpm}$. The optimal aeration rates for cell growth and production of CMCase were $1.0 \mathrm{vvm}$. The optimal agitation speed and aeration rate for cell growth of $E$. coli JM109/LBH-10 were the same as those for its production of CMCase.

Based on the results from one-factor-at-a-time, the effect of agitation speed and aeration rate on cell growth and the production of CMCase by E. coli JM109/LBH-10 were investigated using RSM. The coded values of minimum and maximum ranges of agitation speed $\left(\mathrm{X}_{1}\right)$ and aeration rate $\left(\mathrm{X}_{2}\right)$ were 300 and $500 \mathrm{rpm}$ and 0.5 and $1.5 \mathrm{vvm}$. Cell growth $\left(\mathrm{Y}_{1}^{\prime}\right)$ and production of CMCase $\left(\mathrm{Y}_{2}^{\prime}\right)$ from 13 different conditions ranged from 4.40 to $6.94 \mathrm{~g} / \mathrm{L}$ and from 334.4 to $572.7 \mathrm{U} /$ $\mathrm{mL}$, as shown Table 4. Multiple regression analysis of the experimental data gave the following second-order polynomial equation to represent the cell growth of E. coli JM109/LBH-10 (Equation 5). The optimal agitation speed and aeration rate for cell growth were $480 \mathrm{rpm}$ and 1.0 $\mathrm{vvm}$. The maximum cell growth of $6.81 \mathrm{~g} / \mathrm{L}$ was predicted by the model.

$$
\mathrm{Y}_{1}^{\prime}=6.59+0.50 \mathrm{X}_{1}-0.05 \mathrm{X}_{2}-0.46 \mathrm{X}_{1} \mathrm{X}_{2}-0.24 \mathrm{X}_{12}-0.90 \mathrm{X}_{22}
$$

The model F-value of 18.07 from ANOVA of cell growth implied that this model was significant, as shown in Table 5. The ANOVA indicated that this model and the model terms of $\mathrm{X}_{1}, \mathrm{X}_{1} \mathrm{X}_{2}$ and $\mathrm{X}_{12}$ were significant ("probe $>\mathrm{F}$ " less 0.0500 ) for cell growth. The regression equation obtained from ANOVA indicated that the multiple correlation coefficient of $\mathrm{R}_{2}$ is 0.9281 . The value of the adjusted determination coefficient (Adj. $R_{2}=0.8767$ ) is very high to advocate for a high significance of this model.

Multiple regression analysis of the experimental data also gave the following second-order polynomial equation to represent the production of CMCase by E. coli JM109/LBH-10 (Equation 6). The optimal agitation speed and aeration rate for production of CMCase were $480 \mathrm{rpm}$ and $1.0 \mathrm{vvm}$, which were the same as those for cell growth. The maximum production of CMCase of $576.8 \mathrm{U} / \mathrm{mL}$ was predicted by the model.

$\mathrm{Y}_{2}^{\prime}=550.64+54.21 \mathrm{X}_{1}+8.40 \mathrm{X}_{2}+4.98 \mathrm{X}_{1} \mathrm{X}_{2}-29.53 \mathrm{X}_{12}-94.88 \mathrm{X}_{22}$

The model F-value of 42.84 from ANOVA of production of CMCase implied that this model was also significant. The ANOVA indicated that this model and the model terms of $\mathrm{X}_{1}$ and $\mathrm{X}_{22}$ were also highly significant model terms. The regression equation obtained from ANOVA indicated that the multiple correlation coefficient of $R_{2}$ was 0.9734 . The value of the adjusted determination coefficient (Adj. $\mathrm{R}_{2}=0.9543$ ) was very high to advocate for a high significance of this

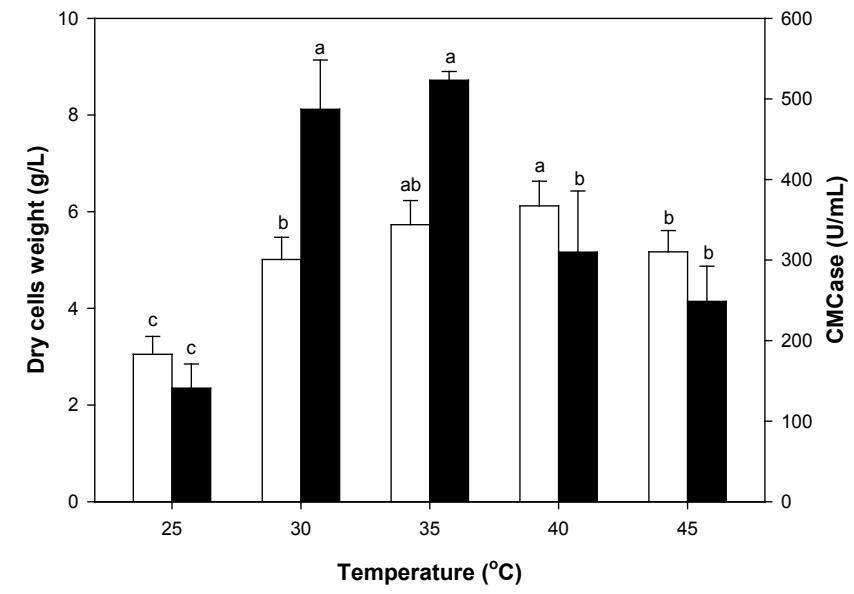

Figure 5: Effect of temperature on cell growth and production of CMCase by E. coli JM109/LBH-10 (๘, cell growth and $\square$, CMCase).

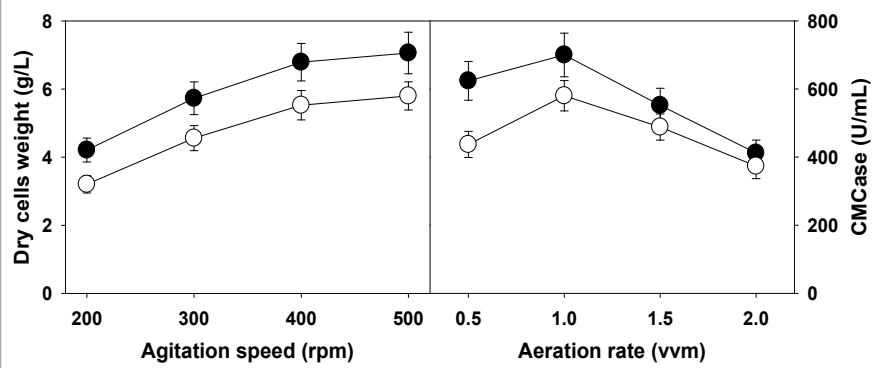

Figure 6: The optimal agitation speed and aeration rate for cell growth and production of PS-7 by E. coli JM109/LBH-10 in a 7L bioreactor ( $\bullet$, DCW and $\circ$, CMCase). 
Citation: Lee SU, Gao W, Chung CH, Lee JW (2014) Construction of Recombinant Escherichia coli JM109/LBH-10 and Comparison of Its Optimal Condition for Production of Carboxymethyl cellulase with Its Wild Type, Psychrobacter aquimaris LBH--10. J Microb Biochem Technol 6: 135-143. doi:10.4172/1948-5948.1000134

model. The predicted determination of coefficient of 0.959 was also in reasonable agreement with the $\mathrm{Adj} . \mathrm{R}_{2}$ of 0.943 .

The three-dimensional response surface plots were generated to investigate the interaction among agitation speed and aeration rate and to visualize the combined effects on the response of cell growth and the production of CMCase by E. coli JM109/LBH-10, as shown in Figure 7 . The three-dimensional response surfaces and their respective contour plots are the graphical representation of Equations 5 and 6 . In contrast to the circular shapes, the elliptical nature of curves indicates more significant mutual interactions between variables. The interactive effect of agitation speed and aeration rate on cell growth (Probe $>\mathrm{F}=$ 0.0209) was found to be higher than that on production of CMCase (Probe $>\mathrm{F}=0.6101$ ).

The concentration of dissolved oxygen in the medium is influenced by agitation speed, aeration rate, and the inner pressure of bioreactors [28]. Variation in agitation speed and aeration rate results in a change in the concentration of dissolved oxygen in the medium, which in turn affects cell growth and the production of microbial metabolites [29]. The optimal agitation speed and aeration rate for the cell growth of $P$. aquimaris LBH-10 had been reported to be different from those for production of CMCase like other Bacillus species [17,22]. However, the optimal agitation speed and aeration rate for cell growth of $E$. coli JM109/LBH-10 were exactly the same as those for production of CMCase. The optimal agitation speed for the cell growth of $E$. coli JM109/A-53 was the same as that for its production of CMCase, whereas its optimal aeration rate for cell growth was different from that for production of CMCase [11].

In this study, rice bran and ammonium chloride were developed as carbon and nitrogen sources for the production of CMCase by $E$. coli JM109/LBH-10. Rice bran from the rice processing industry is produced in large amounts in Korea, as well as other rice producing countries. Low-cost ammonium chloride as a nitrogen source is also available in large quantities. The optimal conditions for cell growth and production of CMCase by E. coli JM109/LBH-10 were found to be different from those for its wild type, $P$. aquimaris LBH-10, as shown in Table 6. The maximal production of CMCase by E. coli JM109/LBH10 was 1.80 times higher than $P$. aquimaris $\mathrm{LBH}-10$. The maximal productions of CMCase by E. coli JM109/A-53 and E. coli JM109/DL-3 were 3.5 and 2.4 times higher than their wild strains, B. subtilis subsp. subtilis A-53 and B. amyloliquefaciens DL-3, respectively [10,11]. A major restriction in enzymatic saccharification of cellulosic materials can be overcome by developing cheap and easy-available substrates,

\begin{tabular}{|c|c|c|c|c|}
\hline Run & $\mathbf{X}_{1}(\mathbf{r p m})$ & $\mathbf{X}_{2}(\mathbf{v v m})$ & $\mathbf{Y}_{1}(\mathbf{g} / \mathbf{L})$ & $\mathbf{Y}_{2}(\mathbf{U} / \mathbf{m L})$ \\
\hline 1 & 400 & 1.0 & $6.54 \pm 0.47$ & $572.7 \pm 41.0$ \\
\hline 2 & 400 & 1.0 & $6.94 \pm 0.58$ & $542.9 \pm 36.2$ \\
\hline 3 & 500 & 0.5 & $6.24 \pm 0.52$ & $472.3 \pm 38.9$ \\
\hline 4 & 541 & 1.0 & $6.94 \pm 0.54$ & $571.4 \pm 39.2$ \\
\hline 5 & 400 & 0.3 & $4.98 \pm 0.38$ & $334.4 \pm 30.7$ \\
\hline 6 & 400 & 1.7 & $4.40 \pm 0.45$ & $373.5 \pm 29.3$ \\
\hline 7 & 500 & 1.5 & $5.52 \pm 0.36$ & $488.2 \pm 33.4$ \\
\hline 8 & 400 & 1.0 & $6.62 \pm 0.42$ & $531.7 \pm 42.1$ \\
\hline 9 & 300 & 1.5 & $5.76 \pm 0.44$ & $384.1 \pm 32.7$ \\
\hline 10 & 259 & 1.0 & $5.08 \pm 0.39$ & $397.9 \pm 36.5$ \\
\hline 11 & 400 & 1.0 & $6.52 \pm 0.41$ & $537.3 \pm 39.8$ \\
\hline 12 & 300 & 0.5 & $4.65 \pm 0.47$ & $388.1 \pm 32.0$ \\
\hline 13 & 400 & 1.0 & $6.32 \pm 0.51$ & $568.6 \pm 41.3$ \\
\hline
\end{tabular}

Table 4: Central composite design (CCD) and determined response values.

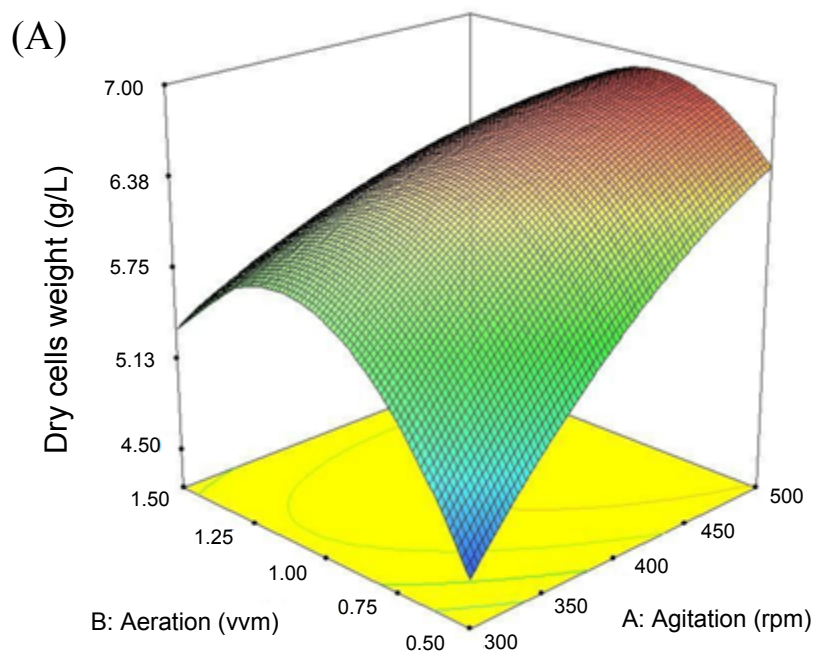

(B)

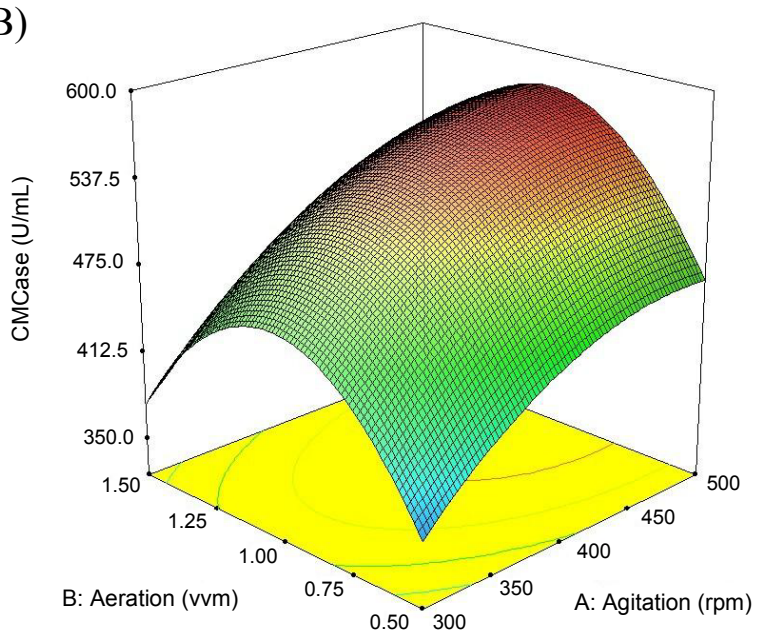

Figure 7: 3D response surface plots displaying combined effect of agitation speed and aeration rate on cell growth $(A)$ and production of CMCase (B) by E. coli JM109/LBH-10.

\begin{tabular}{|c|c|c|c|c|c|c|}
\hline & $\begin{array}{l}\text { Source of } \\
\text { variation }\end{array}$ & $\begin{array}{l}\text { Degree of } \\
\text { freedom }\end{array}$ & $\begin{array}{l}\text { Sum of } \\
\text { squares }\end{array}$ & $\begin{array}{c}\text { Mean } \\
\text { squares }\end{array}$ & $F$-value & Probe $>F$ \\
\hline \multirow{8}{*}{$\begin{array}{l}\text { Cell } \\
\text { growth }\end{array}$} & Model & 5 & 8.59 & 1.72 & 18.07 & 0.0007 \\
\hline & $X_{1}$ & 1 & 1.98 & 1.98 & 20.82 & 0.0026 \\
\hline & $x_{2}$ & 1 & 0.02 & 0.02 & 0.24 & 0.6370 \\
\hline & $X_{1} \cdot X_{2}$ & 1 & 0.84 & 0.84 & 8.80 & 0.0209 \\
\hline & $\mathrm{X}_{1}^{2}$ & 1 & 0.40 & 0.40 & 4.24 & 0.0784 \\
\hline & $X_{2}^{2}$ & 1 & 5.65 & 5.65 & 59.36 & 0.0001 \\
\hline & Error & 4 & 0.20 & 0.05 & - & - \\
\hline & Total & 12 & 9.26 & - & - & - \\
\hline \multirow{8}{*}{ CMCase } & Model & 5 & 90416.0 & 18083.2 & 42.84 & $<0.0001$ \\
\hline & $X_{1}$ & 1 & 23508.3 & 23508.3 & 55.70 & $<0.0001$ \\
\hline & $x_{2}$ & 1 & 564.4 & 564.4 & 1.34 & 0.2433 \\
\hline & $X_{1} \cdot X_{2}$ & 1 & 99.0 & 99.0 & 0.23 & 0.6101 \\
\hline & $X_{1}^{2}$ & 1 & 6482.5 & 6482.5 & 15.36 & 0.0042 \\
\hline & $X_{2}^{2}$ & 1 & 63946.1 & 63946.1 & 151.51 & $<0.0001$ \\
\hline & Error & 4 & 1927.0 & 481.8 & - & - \\
\hline & Total & 12 & 93370.5 & - & - & - \\
\hline
\end{tabular}

Table 5: Parameter estimates and analysis of variance (ANOVA) of the design for cell growth and production of CMCase by E. coli JM109/LBH-10. 
Citation: Lee SU, Gao W, Chung CH, Lee JW (2014) Construction of Recombinant Escherichia coli JM109/LBH-10 and Comparison of Its Optimal Condition for Production of Carboxymethyl cellulase with Its Wild Type, Psychrobacter aquimaris LBH--10. J Microb Biochem Technol 6: 135-143. doi:10.4172/1948-5948.1000134

\begin{tabular}{|c|c|c|c|c|c|}
\hline \multirow[t]{2}{*}{ Scale } & \multirow[t]{2}{*}{ Optimal condition } & \multicolumn{2}{|c|}{ E. coli JM109/LBH-10 [This study] } & \multicolumn{2}{|c|}{ P. aquimaris LBH-10 [13] } \\
\hline & & Cell growth & CMCase & Cell growth & CMCase \\
\hline \multirow{4}{*}{$\begin{array}{l}\text { Flask } \\
\text { scale-1 }\end{array}$} & Rice bran (g/L) & 73.4 & 57.1 & - & 50.0 \\
\hline & Ammonium chloride $(\mathrm{g} / \mathrm{L})$ & 5.80 & 6.40 & - & $3.0^{*}$ \\
\hline & Initial pH & 6.54 & 6.70 & - & 8.0 \\
\hline & Maximal production & $6.21 \mathrm{~g} / \mathrm{L}$ & $388.9 \mathrm{U} / \mathrm{mL}$ & - & $221.8 \mathrm{U} / \mathrm{mL}$ \\
\hline \multirow{2}{*}{$\begin{array}{l}\text { Flask } \\
\text { scale-2 }\end{array}$} & Temperature $\left({ }^{\circ} \mathrm{C}\right)$ & 40 & 35 & 25 & 30 \\
\hline & Maximal production & $6.12 \mathrm{~g} / \mathrm{L}$ & $523.3 \mathrm{U} / \mathrm{mL}$ & $2.32 \mathrm{~g} / \mathrm{L}$ & $334.6 \mathrm{U} / \mathrm{mL}$ \\
\hline \multirow{3}{*}{ Bioreactor } & Agitation speed (rpm) & 480 & 480 & 400 & 300 \\
\hline & Aeration rate (vvm) & 1.0 & 1.0 & 1.5 & 1.0 \\
\hline & Maximal production & $6.81 \mathrm{~g} / \mathrm{L}$ & $576.8 \mathrm{U} / \mathrm{mL}$ & $3.36 \mathrm{~g} / \mathrm{L}$ & $320.3 \mathrm{U} / \mathrm{mL}$ \\
\hline
\end{tabular}

*Nitrogen source was peptone

Table 6: Comparison of optimal conditions for cell growth and production of CMCase by $P$. aquimaris LBH-10 and its recombinant $E$. coli JM109/LBH-10.

\section{Acknowledgements}

This research was financially supported by the Ministry of Education, Science Technology (MEST) and National Research Foundation of Korea (NRF) through the Human Resource Training Project for Regional Innovation.

\section{References}

1. Kang HK, Kim NM, Kim GJ, Seo ES, Ryu HJ, et al. (2011) Enhanced sacchrification of rice straw using hypochlorite-hydrogen peroxide. Biotechnology and Bioprocess Engineering 16: 273-281.

2. Yi JC, Sandra JC, John AB, Shu TC (1999) Production and distribution of endoglucanase, cellobiohydrolase, and ß-glucosidase components of the cellulolytic system of Volvariellavolvacea, the edible straw mushroom. Applied and Environmental Microbiology 65: 553-559.

3. Wei GY, Lee YJ, Kim YJ, Jin IH, Lee JH, et al. (2010) Kinetic study on the pretreatment and enzymatic saccharification of rice hull for the production of fermentable sugars. ApplBiochemBiotechnol 162: 1471-1482.

4. Wei GY, Gao W, Jin IH, Yoo SY, Lee JH, et al. (2009) Pretreatment and saccharification of rice hulls for the production of fermentable sugars. Biotechnology and Bioprocess Engineering 14: 828-834.

5. Kim KC, Kim SW, Kim MJ, Kim SJ (2005) Saccharification of foodwastes using cellulolytic and amylolytic enzymes from Trichodermaharzianum FJ1 and its kinetics. Biotechnology and Bioprocess Engineering 10: 52-59.

6. Jecu $L$ (2000) Solid state fermentation of agricultural wastes for endoglucanase production. Industrial Crops and Products 11: 1-5.

7. Thumar JT, Singh SP (2011) Repression of alkaline protease in salt-toleran alkaliphilic Streptomyces clavuligerus strain Mit-1 under influence of amino acid in minimal medium. Biotechnology and Bioprocess Engineering 16: 1180-1186.

8. Kim HJ, Lee YJ, Chung CH, Lee JW (2010) Characterization of acidic carboxymethylcellulase produced by a marine microorganism Psychrobacteraquimaris LBH-10. Journal of Life Science 20: 487-495.

9. Sukumaran RK, Singhania RR, Mathew GM, Pandey A (2009) Cellulase production using biomass feed stock and its application in lignocellulose saccharification for bio-ethanol production. Renewable Energy 34: 421-424.

10. Lee EJ, Kim HJ, Gao W, Chung CH, Lee JW (2012) Statistical optimization for production of carboxymethylcellulase of Bacillus amyloliquefaciens DL-3 by a recombinant Escherichia coli JM109/DL-3 from rice bran using response surface method. Biotechnology and Bioprocess Engineering 17: 227-235.

11. Lee EJ, Lee BH, Kim BK, Lee JW (2013) Enhanced production of carboxymethylcellulase of a marine microorganism, Bacillus subtilis subsp. subtilis A-53 in a pilot-scaled bioreactor by a recombinant Escherichia coli JM109/A-53 from rice bran. MolBiol Rep 40: 3609-3621.

12. Kulakova L, Galkin A, Nakayama T, Nishino T, Esaki N (2004) Cold-active esterase from Psychrobacter sp. Ant300: gene cloning, characterization, and the effects of Gly-->Pro substitution near the active site on its catalytic activity and stability. BiochimBiophysActa 1696: 59-65.

13. Kim HJ, Lee YJ, Gao W, Chung CH, Son CW, Lee JW (2011) Statistical optimization of fermentation conditions and comparison of their influences on production of cellulases by psychrophilic marine bacterium, Psychrobacteraquimaris LBH-10 using orthogonal array method. Biotechnology and Bioprocess Engineering 16: 542-548.
14. Kim HJ, Lee YJ, Gao W, Chung CH, Lee JW (2012). Optimization of salts in medium for production of carboxymethylcellulase by a psychrophilic marine bacterium, Psychrobacteraquimaris $\mathrm{LBH}-10$ using two statistical methods. Korean Journal of Chemical Engineering 29: 384-391.

15. Lee YJ, Kim BK, Lee BH, Jo KI, Lee NK, et al. (2008) Purification and characterization of cellulase produced by Bacillus amyoliquefaciens DL-3 utilizing rice hull. BioresourTechnol 99: 378-386.

16. Birch PR, Sims PF, Broda P (1995) Substrate-dependent differential splicing of introns in the regions encoding the cellulose binding domains of two exocellobiohydrolase l-like genes in Phanerochaetechrysosporium. Appl Environ Microbiol 61: 3741-3744.

17. Lee BH, Kim BK, Lee YJ, Chung CH, Lee JW (2009) Industrial scale of optimization for the production of carboxymethylcellulase from rice bran by a marine bacterium, Bacillus subtilis subsp. subtilis A-53. Enzyme and Microbial Technology 46: 38-42.

18. Kim HJ, Gao W, Chung CH, Lee JW (2011) Statistical optimization for production of carboxymethylcellulase from rice hulls by a newly isolated marine microorganism Bacillus licheniformis LBH-52 using response surface method. Journal of Life Science 21: 1083-1093.

19. Fukumori F, Sashihara N, Kudo T, Horikoshi K (1986) Nucleotide sequences of two cellulase genes from alkalophilic Bacillus sp. strain N-4 and their strong homology. J Bacteriol 168: 479-485.

20. Nielsen H, Engelbrecht J, Brunak S, von Heijne G (1997) Identification of prokaryotic and eukaryotic signal peptides and prediction of their cleavage sites. Protein Eng 10: 1-6.

21. Ohmiya K, Sakka K, Karita S, Kimura T (1997) Structure of cellulases and their applications. Biotechnol Genet Eng Rev 14: 365-414.

22. Jo KI, Lee YJ, Kim BK, Lee BH, Chung CH, et al. (2008) Pilot-scale production of carboxymethylcellulase from rice hull by Bacillus amyloliquefaciens DL-3. Biotechnology and Bioprocess Engineering 13: 182-188.

23. Lee YJ, Kim HJ, Gao W, Chung CH, Lee JW (2011) Comparison of statistical methods for optimization of salts in medium for production of carboxymethylcellulase of Bacillus amyloliquefaciens DL-3 by a recombinant E. coli JM109/DL-3. Journal of Life Science 21: 1205-1213.

24. Gao W, Lee EJ, Lee SU, Li J, Chung CH, et al. (2012) Enhanced carboxymethylcellulase production by a newly isolated marine bacterium, Cellulophagalytica LBH-14, using rice bran. J MicrobiolBiotechnol 22: 14121422.

25. Kim YJ, Cao W, Lee SU, Lee JW (2012) Enhanced production of carboxymethylcellulase by a newly isolated marine microorganism Bacillus atrophaeus $\mathrm{LBH}-18$ using rice bran, a byproduct from the rice processing industry. Journal of Life Science 22: 1295-1306.

26. Li D, Fu X, Kim SM (2010) Production of chumsalmoncystain from the recombinant Saccharomyces cerevisiae optimized using response surface methodology. Biotechnology and Bioprocess Engineering 15: 314-323.

27. Kim BK, Kim HJ, Lee JW (2013) Rapid statistical optimization of cultura conditions for mass production of carboxymethylcellulase by a newly isolated marine bacterium, Bacillus velezensis A-68 from rice hulls. Journal of Life Science 23: 757-769. 
Citation: Lee SU, Gao W, Chung CH, Lee JW (2014) Construction of Recombinant Escherichia coli JM109/LBH-10 and Comparison of Its Optimal Condition for Production of Carboxymethyl cellulase with Its Wild Type, Psychrobacter aquimaris LBH--10. J Microb Biochem Technol 6 : 135-143. doi:10.4172/1948-5948.1000134

28. Gao W, Lee SU, Li JH, Lee JW (2013) Enhanced production of carboxymethylcellulase by Cellulophagalytica LBH-14 in pilot-scale bioreactor under optimized conditions involved in dissolved oxygen. Korean Journal of Chemical Engineering 30: 1105-1110.
29. Gao W, Kim HW, Li JH, Lee JW (2013) Enhanced production of cellobiase by a marine bacterium, Cellulophagalytica LBH-14, in pilot-scaled bioreactor using rice bran. Journal of Life Science 23: 542-553. 